Pobrane z czasopisma New Horizons in English Studies http://newhorizons.umcs.pl

Data: 26/04/2023 09:17:39

New Horizons in English Studies 5/2020

\title{
LITERATURE
}

$\infty$

\author{
Monika Kosa \\ Babeș-BOLYai University, Romania \\ KOSAMONIKA@YAHOO.COM \\ HTTPS://ORCID.ORG/OOOO-0OO2-1039-9989
}

\section{Revisiting the Monster Tale: Frankensteinian Tropes in Margaret Atwood's Speculative Fiction}

\begin{abstract}
Mary Shelley's iconic Frankenstein is a pivotal work in the Western canon. Since its publication in 1818, the novel has been re-written and adapted many times. Shelley's magnum opus sublimely evokes the postlapsarian condition of the fallen, while also capturing the imminent fear of technology, scientific progress and artificial procreation. The paper aims to explore the Frankenstein legacy and the development of Frankensteinian motifs in Atwood's speculative fiction. More precisely, the paper focuses on The Handmaid's Tale (1985), The MaddAddam Trilogy - Oryx and Crake (2003), The Year of the Flood (2009), MaddAddam (2013), and The Heart Goes Last (2015), analyzing how postmodern literature recycles and incorporates elements from Frankenstein to reflect (on) contemporary anxieties and to insist on the fluid discursivity of monstrosity.
\end{abstract}

Keywords: Frankenstein, speculative fiction, Margaret Atwood, Canadian literature, monstrosity

\section{Introduction: The Frankensteinian legacy}

Shelley's iconic Frankenstein (1818) is a pivotal work in the Western canon and is ubiquitous in popular culture. Shelley's penchant for teratological iconography and transgressive imagery pinnacles in her widely-celebrated magnum opus, Frankenstein, which continues to spawn an array of literary texts and is a source text for endless adaptations: as Rebecca Bauman notes, "Frankenstein has become a nexus, a node, a universe unto itself, spawning and inspiring new texts, new ideas, and new monsters" (2018, xix). Its immense impact on the development of Anglophone literatures ensures 
its lasting legacy, validating the universality of its themes and innovative approach to teratogeny. ${ }^{1}$

As Shelley's monster "may be the most famous monster of the past two centuries" (Asma 2009, 151), its prevalence in Anglophone literature and popular culture is only to be expected. As it turns out, Shelley's enduring magnum opus reflects the anxieties besetting not only nineteenth-century cultures, but contemporary societies as well, specifically fears triggered by scientific, political and cultural transgressions. At the same time, Frankenstein articulates an atavistic fear of scientific omnipotence and the precarious transhumanist ${ }^{2}$ potentialities of biosciences, which is a recurrent thematic concern in contemporary science fiction as well as posthumanist and dystopian texts.

\section{Monster narratives and the teratological imagination: Margaret Atwood's speculative fiction and Frankenstein}

During her long and successful writing career, Margaret Atwood has mentioned her indebtedness to fairytales, celebrated novels and canonical texts (such as the Bible) as inspirations for her own writing. For instance, in The Handmaid's Tale and Oryx and Crake, Howells identifies "Swift's Gulliver's Travels, H.G. Wells's The Island of Dr Moreau, and most hauntingly Mary Shelley's Frankenstein" $(2006,164)$ as the main intertextual references. Atwood accommodates - often resorting to parody ${ }^{3}$ - allusions in her novels not only to create a complex web of connections ${ }^{4}$ but also to initiate a Hadean descent into literature's archives of monstrosity. In this way, she is persuading her readers to engage in a moral re-evaluation of contemporary scientific practices with

1 Teratogeny is a concept originating from biology and it refers to "the creation of malformed individuals," as defined in the online edition of the Collins Dictionary.

2 Transhumanism refers to a philosophical movement which advocates the "enhancement of human intellectual, physical, and emotional capabilities, the elimination of disease and unnecessary suffering, and the dramatic extension of life span" (Wolfe 2010, xiii) and "promotes the use of biotechnologies to modify and improve our nature, to transform us into a different kind of being. Guiding ideas are the desirability of human self-design, the elimination of all suffering and expansion of human autonomy, immortality, and ultimately the complete defeat of (human) nature" (Hauskeller 2016, 3). In other words, transhumanists believe in the possibility of transcending the human condition by resorting to science, an idea that is explored in several literary narratives, including Frankenstein.

3 Parody is central in Atwood's speculative fiction, as in many other postmodern narratives, being "one of the major modes of formal and thematic construction of texts" (Hutcheon 2000, 2) in the twentieth-century. Witty, playful and ironic, Atwood's inherently parodic revisiting of Shelley's narrative offers an alternative reading of the monster-trope, challenging deeply entrenched cultural myths and subverting literary conventions.

4 Frankenstein influenced not only Atwood's speculative fiction, but her poetry as well. In 1966, Atwood wrote "Speeches for Doctor Frankenstein," an idiosyncratic collection of shorter poems inspired by and dedicated to Frankenstein, with illustrations by Charles Pachter. Part of the Canadian cultural heritage, only a limited number of fifteen books were published. 
monstrous potentiality, most notably genetic engineering and biotechnology, which could alter human subjectivity and precipitate planetary doom, confirming, indeed, that "we live in a time of monsters," as Cohen aptly put it in the Preface to Monster Theory (1996, vii).

Contemporary cultures are saturated with anxieties related to environmental issues, genetic engineering, pandemics and technology-related concerns, and Atwood's dystopic narratives encapsulate these darker aspects and fears of the present. By projecting the uncanny zeitgeist, Atwood canvasses a panoramic view of the sociocultural context of recent history with special focus on political and cultural crises. Atwood's long-term interest in monsters dates back to 1977, when she wrote the essay "Canadian Monsters: Some Aspects of the Supernatural in Canadian Fiction," which categorizes Canadian types of monstrosities. Paradoxically, the starting point of her investigation is that "magic and monsters don't usually get associated with Canadian literature" because "Canadian fiction on the whole confines itself to ordinary life on middle-earth" $(2018,230)$; indeed, conventional realism was the dominant trend in Canadian literature until the second part of the twentieth century. However, Atwood argues, "there is more to Kanada ${ }^{5}$ than meets the eye" $(2018,252)$ and Canadian monsters certainly do exist. Atwood identifies four recurring monster-tropes in Canadian literature: the wendigo and the Coyote in earlier narratives, which are metaphors for "Monsters as Other" (Atwood 2018, 252), the magician-figure in the twentieth-century, who seems "rather more concerned, symbolically, with man's relationship to his society and to himself" (252) and lastly, the wabeno, a creature from Native American lore, which symbolizes "the desire for power through the destruction of others, which in the end is the same as self-destruction" (251).

Atwood's own dystopian narratives are saturated with different representations of monstrosity, reflecting her interest in teratogenic figurations. Atwood enriches the contemporary teratogenic imagination with monsters that incarnate devilish aspects of politics, culture, and science. More precisely, Atwood examines political monstrosity by constructing the bloody realm of Gilead, the handmaid-figure illustrating monstrified femininity, while the mad genius of eugenics, the twenty-first century bioterrorist, is embodied in Crake, and the evil twin cities Positron/Consilience are spatial incarnations of corporate power.

Over the centuries, teratology - the science of monsters - suffused academic discourses and generated heated theoretical debates over the complex nature of monsters, dating as far back as the proto-teratological text by Aristotle's titled On the Generation of Animals, which "investigates the causes of monstrous generation" (Borbely 2015, 43). Rooted in nineteenth-century "teratogenic experiments and taxonomical studies of the Saint-Hilaires" (Borbely 2015, 48), teratology as a legitimized discipline of

5 Kanada is a fictionalized version of Canada in Gwendolyn MacEwen's short story collection, Nomad, published in 1972. 
anatomical malformations regards the biological regulation of monstrosity. ${ }^{6}$ In contemporary times, the pathology of monstrosity and the teratological imagination are approached from different and varied theoretical frameworks, including Foucault's political monster theory, Cohen's contribution to cultural studies by proposing to read "cultures from the monsters they engender" $(1996,3)$, or Braidotti's feminist concept of the complexity of monstrous female bodies, monstrous births, and "the subject of the maternal imagination" $(1999,299)$ as the locus of monstrosity.

Given the complexity of the notion of monstrosity and the variety of discourses ranging from scientific debates to literary narratives - on teratological figurations, this paper proposes reading monstrosity "as a historically variable, discursive construction of otherness, arising at the nexus of a wide array of cultural, religious and ideological discourses" (Borbely 2015, 9). In Atwood's speculative fiction, monstrosity is indeed symptomatic of the cultural and political climate of its historical context. These hauntingly atmospheric novels recycle and incorporate elements from Frankenstein to reflect (on) contemporary anxieties, to insist on the fluid discursivity of monstrosity and simultaneously to embed the perils of political and corporate power, eugenics, environmental damage and religious fanaticism, all being pressing issues of contemporaneity.

In her speculative novels Atwood translates "the dystopian impulse to shock readers into an awareness of dangerous trends in our present world" (Howells 2006, 164) since these narratives function as cautionary tales against amoral scientific and political practices (notably exposing the horrors of totalitarian regimes and capitalist economies), which could endanger the future of humanity and demystifies, by means of parody, the transhumanist ideal, which is a leitmotif in many popular science fiction narratives such as Blade Runner or The Matrix. In a similar vein, the original Frankenstein narrative cautions against unethical scientific pursuits as Shelley's text takes inspiration from "the discussions at Diodati about the origins of life and the experiments on galvanism" (Nitchie 1970, 27).

Concerned with exploring the role of the scientist and exposing the pitfalls of technological advancements, Frankenstein "exemplified the Romantic rejection of the eighteenth-century Cartesian belief in the scientist as hero and in technology as inherently good" and "popularized what was to become a standard nineteenth-century sf archetype: the mad scientist who, in his hubris-filled pursuit of knowledge and power, betrays basic human values" (Evans 2009, 13). Victor Frankenstein, the Byronic prototype of the "egomaniac, the unethical scientist" (Baumann 2018, xvii) thus instantiates a radical departure from the traditional villain archetype and paves the way for new typologies. ${ }^{7}$

6 For more details on the history of monstrosity and teratogenic taxonomies, see Borbely, Towards a Genealogy of Monstrosity (2015).

7 For instance, Crake from The MaddAddam Trilogy is Atwood's idiosyncratic version of Frankenstein. Crake epitomizes the post-Faustian bioterrorist, who uses advanced biotechnology to radically alter (and possibly annihilate) mankind. 


\section{Monster-narrative and contemporary politics: The Handmaid's Tale}

Atwood's most famous novel to date - The Handmaid's Tale 8 - is a timeless masterpiece which, as Dvorak warns us, "is not to be read simply as a prophecy or cautionary tale, but as a reflexion on our contemporary political and social practices" (2001, 141). Reimagining the United States as an oppressive theocracy where women are systematically dehumanized and categorized as handmaids, aunts or wives, the novel problematizes political teratology and institutionalized misogyny as well as the social, cultural, ethical and sexual implications of totalitarian regimes by creating the inherently Gothicized realm of Gilead and its monstrous subjects. Harold Bloom describes the novel as an inherently Gothic narrative:

The Handmaid's Tale emerges from the strongest strain in Atwood's imaginative sensibility, which is Gothic. A Gothic dystopia is an oddly mixed genre, but Atwood makes it work. Offred's tone is consistent, cautious, and finally quite frightening. Atwood, in much, if not most, of her best poetry and prose, writes Northern Gothic in the tradition of the Brontës and of Mary Shelley. [...] Her Gilead, at bottom, is a vampiric realm, a society sick with blood. $(2001,2)$

The bloody realm of Gilead reflects the horrors from within, becoming an external projection of the vampiric regime that oppresses and feeds off its vulnerable subjects.

The Handmaid's Tale encloses (and simultaneously exposes) individual histories within the confines of the restrictive Gileadean regime. Set in a dystopian future yet based on historical facts ${ }^{9}$, Offred' $\mathrm{s}^{10}$ tale reveals systematic dehumanization of female subjects against the backdrop of a monstrous patriarchal and theocratic society bent on subjugating women and stripping them of their subjectivity. Reminiscent of an Orwellian nightmare, the novel translates Offred's unsettling life story of subjugation into a dystopian narrative structured in such a way as to both embed and estrange historical, cultural and literary references.

8 The recent Hulu serialization of the novel (2017-) has contributed to the novel's international fame. Created by Bruce Millar, the series stars Elisabeth Moss, Max Minghella and Amanda Brugel, has three seasons so far and won several prestigious awards since its premiere.

9 The Handmaid's Tale is partly inspired by Ronald Reagan's conservative presidency (1981-1989), Nicolae Ceaușescu's communist propaganda, which aimed to enhance birth rates by banning abortion, Ferdinand Marcos' bloody dictatorship in the Philippines, and the American Plan, a twentieth-century practice of imprisoning women who were suspected of sexually transmittable infections as an attempt to protect American soldiers from becoming infected. At the heart of the novel, however, lies American Puritanism, which dates back to seventeenth-century New England. Atwood "drew connections between what was happening in the US in the 1980s and the original Puritan colonists in $17^{\text {th }}$ century New England" (Armstrong). In the twenty-first century, Atwood's novel is more relevant than ever, given the political climate of the United States under the Trump administration and the abortion-related concerns resurfacing in different parts of the world.

10 Offred is the main character and the narrator of The Handmaid's Tale. 
The Handmaid's Tale parodically exposes the interplay of power and science, as well as the problematic notion of procreation, problematizing women's role as mothers in society and their right to bodily autonomy. Atwood shifts procreational authority to patriarchal institutions and exposes the devastating consequences of female objectification, which implies reducing women to mere reproductive instruments or state-controlled sex slaves. In the Republic of Gilead, women (more specifically, handmaids) are reduced to "two-legged wombs [...] sacred vessels, ambulatory chalices" (Atwood 1985, 143).

Like the monster from Shelley's narrative, the handmaids are dehumanized as women and ritualistically assigned a teratogenic identity, i.e. they are monstrified by the political regime and systematically objectified, state oppression acting as both a monstrifying agency and a monstrified agent. Alienated, silenced, dehumanized, and objectified, Frankentein's creature and the handmaids are symptomatic of a culture in crisis, relegated to exist on the fringe of civilization and political power; in Offred's words, "we were the people who were not in the papers. We lived in the blank white spaces at the edges of print [...]. We lived in the gaps between the stories" (Atwood 1985, 53). Moreover, the handmaids and Frankenstein's monster share similarities in terms of their (in)visibility, lack of individuality, and social marginalization, ${ }^{11}$ thus becoming expressive of the complex interplay between totalitarian tyranny and ritualistic monstrification of the (gendered) Other.

\section{On contemporary anxieties: The MaddAddam Trilogy}

The MaddAddam Trilogy, especially the first book, Oryx and Crake, relies on Frankensteinian tropes as the novel satirically denounces

contemporary society's easy reliance on and unthinking acceptance of computer data storage of personal information, genetic modification and a myriad of other scientific interventions [...], or the world's complacency in the face of environmental shifts. (Macpherson 2010, 53)

Oryx and Crake is inspired by contemporary scientific research and deploys refurbished cultural and literary tropes to raise awareness of humanity's alarmingly apathetic stance on political, ecological and scientific practices. The novel denunciates the estranging principles of artificial procreation and radical eugenics by exposing the dire

11 Like Frankenstein's creature, handmaids are socially invisible in Gilead. The only time when Offred is allowed to have thoughts is during the night, under the veil of darkness and silence: "The night is mine, my own time, to do with as I will, as long as I am quiet. As long as I don't move. As long as I lie and lay" (Atwood 1985, 35). The prohibition to showcase signs of humanity corporally and/or behaviorally - is the main tool of deprivation and conformability employed by the Republic of Gilead to forcibly subdue its objectified subjects. 
consequences of scientific transgressions as embodied in Shelley's proto-monster and Atwood's ne plus ultra transhumans, the Crakers.

Oryx and Crake meditates on the quintessentially Shelleyan question: "How much is too much, how far is too far?" (Atwood 2003, 206). Atwood insists on the idea that genetic engineering opens up a series of ethical questions about human nature and the human right to privacy (Reiss 2001, 13), amplifying the Shelleyan ethics/ science conundrum in order to incorporate the perils of genome editing in her monster tale. In addition, Atwood codifies (often by means of parody, a practice characteristic for her narratives) existing scientific advancements over future prospects of planetary doom, both in environmental and moral terms, to caution her readers about the risks of biotechnology and its destructive potential. From a cultural perspective, Atwood's satirical slant on consumerism deplores the gradual dehumanization of capitalist societies and consequent cultural sterility: her "virtual-reality scenarios represent modern nightmares, where the post-catastrophe world [...] is preceded by Atwood's ferocious satire on late modern American capitalist society" (Howells 2006, 164).

In Oryx and Crake, the corrupting scientific hubris is constructed as a social disease that brings about the apocalypse. ${ }^{12}$ The dystopian narrative speculates on the apocalyptic potentiality of eugenics and

projects a world defamiliarized not through military or state power but through the abuse of scientific knowledge, where genetic engineering has created transgenic monsters and humanoid creatures in a post-apocalyptic scenario [...]. (Howells 2006, 163)

The first paragraphs of the novel function as a Kafkaesque prelude to Snowman's unsettling survival-narrative, which juxtaposes his earlier memories with the post-apocalyptic present. Oryx and Crake is the story of Snowman, who survived a pandemic that wiped out mankind, and now lives in a post-apocalyptic world with the humanoid Crakers. Flashbacks reveal that before the self-identification with the semi-mythical Abominable Snowman - a consequence of the new world order following Crake's deadly pandemic that supposedly eradicated mankind - the protagonist was named Jimmy. As a living reminder of the perennial hope of communal rebirth in the aftermath of a deadly pandemic, Snowman is the forlorn by-product of Crake's transhumanist $\mathrm{u}(\mathrm{s})$ topia. ${ }^{13} \mathrm{Crake}$, Atwood's version of the mad scientist, is a genius in biosciences, who, driven by a eugenics-based rationale, fixes on annihilating mankind and replacing humans with genetically engineered posthumans called Crakers. ${ }^{14}$ Intent

12 In biblical terms, Crake's apocalypse corresponds to the second Fall of Man.

13 In the article "Margaret Atwood: The Road to Ustopia," Atwood explains that "ustopia is a world I made up by combining utopia and dystopia - the imagined perfect society and its opposite because, in my view, each contains a latent version of the other" (2011).

14 For more information on the Crakers as posthumans, see Schmeink's "The Anthropocene, the Posthuman, and the Animal" (2016). 
on playing God, Crake envisions and creates a brave new world of mass chaos and wanton destruction.

The Abominable Snowman, who is first glanced in a ludicrous posture climbing down a tree, is a specular reflection of the dystopic zeitgeist of Atwood's post-historic wasteland. The Abominable Snowman's freakish appearance and evocative name reveal an intentional reference to Frankenstein. ${ }^{15}$ Snowman is Atwood's witty take on lusus naturae - a freak of nature - a notion that was correlated in the seventeenth-century with monstrosity in scientific discourses (Borbely 2015, 45). Against the backdrop of a post-apocalyptic wasteland, Snowman is as much a conjectural construction as he is a human subject, an idea reinforced by the Crakers, who figuratively narrated him into existence by accumulating "a stock of lore, of conjecture about him" (Atwood 2003, 8).

The character adopts the persona of the mythological Abominable Snowman in the post-pandemic world of the novel, an act that implies assuming a monstrous identity: "the Abominable Snowman - existing and not existing, flickering at the edges of blizzards, apelike man or manlike ape, stealthy, elusive, known only through rumours and through its backward-pointing footprints" (Atwood 2003, 7-8). Snowman's engagement in postmodern, ironical self-questioning reveals his troubling fixation on teratogenic performativity and self-monstrification as a desperate coping mechanism against the estranging milieu.

Ironically, Snowman instantiates (and simultaneously estranges) the Shelleyan teratogeny as he is transmuted into a Calibanic projection of Man, validated only by the Crakers, who legitimize Snowman's abominable persona by accepting "Snowman's monstrousness" as "they've known from the beginning he was a separate order of being" (Atwood 2003, 101). Like Shelley's creature, Coleridge's Ancient Mariner, or Atwood's Offred, Snowman's existential crisis is rooted in his alienated condition engendered by a traumatic past and a profound sense of loneliness stemming from their social alienation and ontological singularity. Snowman's existential rage against an absent creator, enacted in dramatic monologues, articulates a sense of postlapsarian forlornness and directly references Frankenstein.

The alteration of the human condition by means of advanced technoscience results in the appearance of Crake's transhumanist prototype, the Crakers, whose transfigured corporeality and enhanced adaptability help them to replace mankind, becoming a sort of parodic version of the posthuman ideal. In fact, Crake's vision of a brave (and better) new world implies replacing the irremediably flawed pan-human cultures with bioengineered replicas designed to return mankind to the paradisiacal condition of apparently blissful ignorance. In fact, the transgenic Crakers are merely a parody of humans as

15 The term "Abominable Snowman" was first used by Charles Howard-Bury in 1921 after glimpsing the mythical creature in the snow during the 1921 British Mount Everest reconnaissance expedition. Frankenstein's monster is last seen disappearing into the darkness in the North Pole. Thus, an analogy can be drawn between the two fabled monsters in terms of their habitat. 
they are technologically enhanced versions of "the noble savage" (Borbely and Petrar 2014, 149). The Crakers are constructed as estranged hybrids who problematize the notion of (trans)humanity as they "simultaneously deconstruct and reconstruct the significance of the human in the aftermath of the biotechnoscientific paradigm, which has befuddled the chain of creation [...]" (Borbely and Petrar 2014, 146).

As parodic adaptations of Shelley's monster, the quasi-human Crakers reify the transmutational potentialities of transgenics and epitomize the fluidity of teratology by denaturing and mocking the culturally embedded taxonomies of monstrosity. As sites for cultural and ethical discourses of biopoiesis ${ }^{16}$, the pseudo-mythological Crakers can be viewed as parodic simulacra of the transhumanist ideal and "literally the ful filled [sic] ustopia of today's transhumanist ideal" (Borbely and Petrar 2014, 149). Ultimately, both Frankenstein and Oryx and Crake are concerned with an alchemic fascination with creating life - an inherently godly attribute - and both narratives expose the catastrophic consequences of such megalomaniac ambitions.

The second novel in the trilogy, The Year of the Flood, limns the pandemic holocaust depicted in Oryx and Crake from the perspective of two female survivors, Toby and Ren, illustrating the post-apocalyptic adaptation of a group of survivors who belong to the God's Gardeners cult. The title is a biblical reference to Crake's genocide, which the God's Gardeners refer to as The Waterless Flood, and partly reveals the chronotopic frame of the narrative. The shift in perspective enables readers to witness the pre- and post-pandemic events from an "outsider" angle so as to gain a panoramic view of the "compounds" and the gloomy reality of the "pleeblands." Pleeblands are Atwood's version of slums and ghettos; their opposite, the compounds, are wealthy neighborhoods accessible only to scientists and their families.

The novel abounds in religious references, intertextual elements and witty wordplay ${ }^{17}$ which reflect (on) the moral limits of scientificity (a Shelleyan trope par excellence), corporate control, and religious zealotry. Furthermore, intertextuality enhances the estranging effect of the narrative as Atwood displaces familiar elements as dystopian hybrids that barely resemble their sources. The first paragraphs of the novel foreground the trope of Edenic solitariness, a Shelleyan legacy frequently revisited in Atwood's speculative fiction: "the abandoned towers in the distance are like the coral of an ancient reef-bleached and colourless, devoid of life" (Atwood 2009, 9). Further on, the novel revisits the events that led to the apocalypse, yet focuses more on exposing the living conditions in the pleeblands, more precisely on the lives of members of the God's Gardeners cult with special focus on the story of Ren and Toby, two female survivors of the pandemic. The Gardeners - "twisted fanatics who combine food ex-

16 Collin's Dictionary defines biopoiesis as "the development of living matter from nonliving matter, esp. considered as an evolutionary process."

17 Examples include original and highly parodic linguistic constructions, such as Sea/H/Ear Candies, Bimplants, Gro-Op, Mo'Hair, Liobam, Pleebrat, Ararat, CorpSeCorps, violet portabiolet, AnooYoo, SeksMart, ChickieNobs, etc. 
tremism with bad fashion sense and a puritanical attitude towards shopping" (Atwood $2009,54)$ - are a distinct social group serving as a parody of religious fanaticism. Demurring the Frankensteinean belief in scientific omnipotence, the Gardeners espouse Cartesian optimism to caution about the finiteness of human knowledge and divine almightiness as the ultimate referential frame.

Similarly to Frankenstein and Oryx and Crake, The Year of Flood broods over the ethical and social implications of biotechnological experimentation. More precisely, Adam One, the "preacher" of the Gardeners, voices the collective bewilderment at the transgenic experiments on humans and animals, and at the moral conundrums such transhumanist experiments raise ${ }^{18}$ :

the ethical problems raised are troubling: Should we have recourse to insecticides? Is such a mechanized slave bee alive? If so, is it a true Creature of God or something else entirely? We must ponder the deeper implications, my Friends, and pray for guidance. (Atwood 2009, 271)

Adam One's reasoning (albeit speculative) accentuates that:

while relishing the infinite combinatorial possibilities that splicing forges, Atwood's ustopias interrogate the limits of the new teratogeny, which threatens to dismantle the purported unassailable sanctity of species, genus and regnum boundaries [...]. (Borbely and Petrar 2014, 147)

Allegorically, Atwood reflects on the human paradigm in the wake of an era when technological advancements could potentially alter the all-familiar notion of the "human" into a radical vision of otherness, thus, projecting new teratological figurations of the transhumanist paradigm.

The Year of the Flood articulates (or rather reaffirms) Atwood's stance on the relevance of naming in terms of (in)visibility, both in social and identarian terms, in a similar vein to Shelley's Frankenstein. The inhabitants of pleeblands, including cults such as God's Gardeners, are marginalized by the corporate system and forced to stay in the murky realm of the industrial peripheral wastelands. In The Year of the Flood, naming equals being a part of the illiberal social regime that enables corporations to track, control and, in some cases, eliminate unwanted individuals. One symbolic scene that captures the relevance of naming depicts Amanda, a pleebrat and close friend of Ren, as she renounces her worldly name, which used to be her identity. "But," she says, "I don't have an identity now. So I'm invisible" (88). In the nightmarish setting of the The Handmaid's Tale, as well as in The MaddAddam Trilogy, the "nameless" existence has a double function: on the one hand, just like in Shelley's narrative, namelessness

18 Savulescu asks a similar ethical question in The Human Prejudice and the Moral Status of Enhanced Beings: What Do We Owe the Gods: "What are our obligations to other beings who are not human beings like us?" $(2009,215)$. 
is a means of surviving the community's prescriptive normativity and the violence (or even death) inflicted by governmental agencies. On the other hand, however, social invisibility is a means of eradicating individual subjectivity by state power.

MaddAddam (2013) is the last part of the trilogy, which concludes the storylines from the previous novels, renders the surviving community's endeavors to rebuild human civilization, and provides ancillary explanations and speculations on the ontological and ethical framework of their scientifically enhanced environment. The survivors, including Jimmy/Snowman, speculate on the "brave new humans" - the Crakers - deemed as "the strange gene-spliced quasi-humans" (Atwood 2013, 22 23). The semantic shift - the transhuman Crakers trivialized as "strange gene-spliced quasi-humans" (Atwood 2013, 22) - aims to parodically reveal the troubling aspects of transhumanism. Moreover, the perceptional transfiguration implies exposing their precarious status in the post-Crakean universe: unlike Shelley's monster, the survival of the Crakers is bound to human agency. As a matter of fact, since the Crakers cannot be classified taxonomically, their existential precariousness opens up an array of conceptual dichotomies (nature/nurture, human/non-human, good/evil, predestination/ contingency, divinity/humanity):

Genes aren't a total destiny? Nature versus nurture, good can come of evil? There are the epigenetic switches to be considered, and maybe the Painballers just had very, very bad nurturing? Or how about: the Crakers may be more human than we think?" (Atwood 2013, 233).

The quasi-mythological Crakers, like Shelley's creature, embody ontological uncertainty, which raises important philosophical questions, such as the following:

How much of Crake's behaviour is inherited, how much is cultural? Do they even have what you could call a culture, separate from the expression of their genes? Or are they more like ants? What about the singing? Granted, it must be some form of communication, but is it territorial, like the singing of birds, or might it be termed art? (Atwood 2013, 152).

More precisely, the central controversy regarding the Crakers is, on a larger scale, an exploration of the core structures defining human cultures, aiming to crystallize answers to "what features are at the core of our being? What a piece of work is man, and now that we ourselves can be the workmen, what bits shall we chop off? What is it to be human?" (Atwood 2005, 162). Moreover, the novel develops transgressive cartographies of the corporate world of the compounds, contrasting them with the pleeblands, the decaying slums of poverty-stricken communities. One highly symbolic spatial metaphor is the government-funded Frankensteinian incubator, Crake's Paradice Project, a direct and parodic reference to Shelley's text:

Crake has planned the Paradice Project himself. There was a tight security perimeter around it, in addition to the Rejoov barrier wall. Inside that was a park, a microclimate-modifying 
planting of mixed tropical splices, tolerant alike to drought and downpour. At the centre of it all was the Paradice dome, climate-controlled, airlocked, an impenetrable eggshell harbouring Crake's treasure trove, his brave new humans. And at the very centre of the dome he'd placed the artificial ecosystem where the Crakers themselves in all their strange perfection had been brought into being and set to live and breathe. (Atwood 2013, 367)

MaddAddam abounds in direct (and often amusing) intertextual references to Frankenstein to reflect (on) contemporary concerns, such as genetic engineering, biotechnology and climate change. For instance, the Crakers are referred to as "Crake's Frankenpeople" (Atwood 2013, 30), while the feral pigs - as "Frankenbacon" (Atwood 2013, 30). In fact, these jocular allusions underpin the potentialities of the emerging field of epigenetics and the ethical transgressions that genalteration entails. ${ }^{19}$ As Aritha van Herk explains, just like Shelley before her, Atwood "is a consummate artist, yes, but her work also pricks our social and ethical consciousness" (2003); in our contemporary context her warning about the dangers of epigenetics and genalteration seems more relevant than ever.

\section{The Heart Goes Last: a (neo)Gothic nightmare}

Atwood's recently published speculative novel, The Heart Goes Last (2015), is a postmodern tall-tale that focuses on the twisted life journey of a homeless young couple, Charmaine and Stan, and their struggle to survive in a dystopian American reality. ${ }^{20}$ Their despondent lives are radically altered when the possibility to take part in an aberrant and amoral social experiment arises, which implies moving permanently to the twin-cities of Consilience/Positron. The condition is to spend one month in prison, then one month at a luxurious residence, swapping places on a monthly basis, which generates an inescapable and vicious social cycle, and raises questions of freedom, control, and the right to privacy.

The novel reifies the typically Atwoodian dyadic leitmotifs: individual/society, freedom/oppression, ethics/amorality, alienation/inclusion, visibility/invisibility, human/non-human. This is achieved as part of an intricate, self-referential, parodic and "savage surreal adventure that examines self-deception and corporate control" (Harrison 2015). The sense of cosmic alienation - in the Shelleyan vein - permeates the novel from the opening paragraphs, where Stan and Charmaine are sitting in their car and ruminating on their miserable existence:

19 Genalteration is term used by Atwood in Oryx and Crake to refer to digital genetic alterations.

20 The United States is a recurrent dystopic site in Atwood's fiction: for instance, in The Handmaid's Tale, Gilead is Atwood's reimagining of America as a toxic theocracy. In contrast, Canada appears as a safe area, fictionalized as a land of freedom in the novel. 
Stan twists in the front seat, trying to get comfortable. [...] So what can he do? Where can they turn? There's no safe place, there are no instructions. It's like he's being blown by a vicious but mindless wind, aimlessly round and round in circles. No way out. He feels so lonely [...]. (Atwood 2015, “Where?”) $)^{21}$

Atwood limns a dystopic American reality overshadowed by Gothic terror and Atwoodian mischief, reminiscent of the ominous atmosphere in Mary Shelley's eerie tales"2: "He feels pursued by bad luck, as if bad luck is a feral dog, lurking along behind him, following his scent, lying in wait around corners. Peering out from under bushes to fix him with its evil yellow eye" (Atwood 2015, "Where?"). As the narrator explains, with the disintegration of the economic system and the emergence of a "brave new world," the prospect of imminent doom becomes inescapable: "then everything went to ratshit. Overnight, it felt like. Not just in his own personal life: the whole card castle, the whole system fell to pieces, trillions of dollars wiped off the balance sheets like fog off a window" (Atwood 2015, “Where?"). In fact, Atwood parodically misappropriates the social myth of corporate America, cautioning her readers about the precariousness of socioeconomic systems. The material benefits and the "inspiring sense of a shared purpose" for creating "A MEANINFUL LIFE" (Atwood 2015, "Twin City") in exchange for living under constant surveillance pose a twisted ethical conundrum for the poverty-stricken inhabitants of the post-industrial America.

The twin cities of Positron/Consilience - a solution offered by corporate masterminds behind the Positron Project ${ }^{23}$ - offer a social sanctuary from the chaotic wasteland of Atwood's dystopian America. The Positron Project lures and manipulates potential participants in the experiment by resorting to blandishments. This is doubled by Atwood's irony, ultimately meant to accentuate the inherently buoyant futurescape that the leaders of the project aim to map:

We offer not only full employment but also protection from the dangerous elements that afflict so many at this time. Work with like-minded others! Help solve the nation's problems of joblessness and crime while solving your own! Accentuate the positive! (Atwood 2015, "Pitch")

${ }^{21}$ In references to The Heart Goes Last (Kindle version), chapter names are used instead of page numbers.

22 Shelley masterfully accommodates the Gothic mode in several of her narratives, including the novel The Last Man (1826) and in some of her shorter fiction as well, for instance The Transformation.

${ }^{23}$ In The Heart Goes Last, the Positron Project is a twisted social experiment that aims to recruit vulnerable individuals to live in twin-cities: the inhabitants are supposed to live for one month in a suburban home, then to relocate for a month to a prison as inmates, and then to repeat the pattern for the rest of their lives, becoming voluntarily prisoners. 
In fact, the Project is a u(s)topic figuration of an illusory condition, and the greed-driven unscrupulous individuals behind the project seek to ensnare its participants from dire socioeconomic circumstances in a corporate-controlled social garrison. Allegorically, the Positron Project is a twisted variation of the Frankenstenian creation-trope where participation implies an enforced "reanimation" disguised as social rebirth.

Atwood expands the God-complex trope, deeply indebted to Frankenstein, to parodically denunciate the delusionary megalomania of the Planners, and to map a prospective future that reflects absolute corporate control:

They themselves, the incoming Positron Planners - they're heroic! They've chosen to risk themselves, to take a gamble on the brighter side of human nature, to chart unknown territories within the psyche. They're like the early pioneers, blazing a trail, clearing a way to the future: a future that will be more secure, more prosperous, and just all-round better because of them! Posterity will revere them. That's the spiel. (Atwood 2015, "Twin City")

Similarly to Shelley's Gothic landscapes and Atwood's earlier settings, the Positron/Resilience twin cities are wicked cities. Like Gilead, the twin cities in The Heart Goes Last are filled with covert violence, Gothic tropes of entrapment (the prison, the car, the house), and dark secrets. In terms of characters, the monster-archetype is paradoxically reimagined as the comic villain Ed, who is described as a "control-freak body-parts salesman, potential baby-blood vampire" (Atwood 2015, "Shipped"), the capitalist embodiment of a mad scientist whose unscrupulous acts - e.g. illegal organ harvest, sexbot replicas, enforced euthanasia - can be traced back to a capitalist lust for profit. In The Heart Goes Last, Atwood re-visions traditional Gothic archetypes and Shelleyan motifs to expose systematic teratology, i.e. the monstrousness embedded in political systems, which, in fact, is revealed to be rooted in contemporary capitalist practices of mass consumption.

\section{Conclusion}

Hollinger observed that since its early days science fiction "has given us stories about how technoscience is making us strange to ourselves, from the introduction to Victor's Creature as the "originary' subject of an alienating technoscience" $(2009,270)$. In Atwood's speculative fiction, Frankensteinean estrangement acquires political, spatial, ethical and social nuances, and is the catalytic principle governing the stories. In The MaddAddam Trilogy the shift from post-industrial to post-apocalyptic topography is the result of a global catastrophe engendered by Crake's God-complex and his tools of advanced bioscience, with the Crakers acting as the estranged and autonomous technosubjects. In The Handmaid's Tale, teratology is politicized and gendered, problematizing procreation as well as the dehumanization and oppression of women. Finally, in The Heart Goes Last, vulnerable individuals are alienated and controlled by vampiric 
corporations in a Gothicized realm. Atwood's use of intertextual elements illustrates her interest in postmodern cross-referentiality and metafiction as she re-visions earlier tropes to address present-day issues. Atwood's self-referential "moral engagement" (Howells 1996, 10) in canvassing the ever-changing cultural, political, scientific, and social climate is, in fact, a part of the Frankensteinian legacy.

Frankenstein's creature - seen as the monstrous representation of the ghastliest spectacles of human history and as a symbol of the deepest terrors of the mind - is, indeed, one of the most enduring literary tropes in the Western canon. The iconoclastic Frankenstein, science fiction's "earliest incarnation and the paradigm myth for scientific hubris in creating an artificial human being" (Schmeink 2016, 120), is a prototypical posthumanist narrative. It constitutes the source material for a number of works, ranging from science fiction novels to television commercials. Atwood adapts Frankensteinian tropes in her speculative fiction to reveal the fluctuating discursiveness of teratogenic formations in contemporary technocentric environments. Frankenstein both accommodates and challenges the limits of science and human knowledge, exacerbating the demonization of scientific research.

Moreover, like the prototypical Frankenstein, Atwood's speculative fiction participates in "exposing the concept of the human in its problematic discursivity" (Pordzik 2012, 144), embedding and questioning the notional fluidity of teratogenic subjectivity in the Anthropocene. Similarly to Shelley's masterpiece, which "stands as one of the quintessential representations of the fears and hopes engendered by new technologies" (Graham 2002, 62), Atwood's speculative fiction revisits monstrosity as her novels conceptualize the grim future prospects propelled by climate change, bioengineering or transgenics as well as the imminence of political, cultural and social tyranny. Furthermore, Atwood's overhaul of the monster-trope implies conceptual displacement from body horror to an internalized teratology portrayed by the ethical collapse of mad scientists whose immoral deeds are reflective of their monstrous selves. Finally, Shelley's novel explores the trope of alterity embodied in the monster-figure and so do Atwood's speculative narratives.

Atwood's transgressive and playful repositioning of teratogenic formations directly interrogates the cultural myths of consumerist societies, e.g. the American dream. These novels evince the conceptual fluidity of monstrosity by illustrating how the concept of the "monster" has evolved over the centuries, gaining new meanings and shifting from corporeal monstrosity to more allegorical representations. Atwoodian speculative fiction probes the ethical limits of scientific and social engineering, examining - in a characteristically parodic and self-reflexive fashion - transhumanism and eugenics as well as the monstrous facets of despotic political systems and all-controlling corporations. Thus, Atwood masterfully adapts motifs from Shelley's original monster narrative to caution against the disastrous potential of scientific hubris and to reveal the deepest and most terrifying aspects of our contemporary lives, unveiling the teratogenic potentialities of politics, science, consumerism, and greed. Against such teratogenic figurations - Atwood seems to suggest - storytelling and literature have redemptive power and prove the ultimate act of resistance. 


\section{References}

Armstrong, Jennifer Keishin. 2018. Why The Handmaid's Tale is so relevant today. BBC April 25. Accessed 30 June, 2020. https://www.bbc.com/culture/article/20180425-why-thehandmaids-tale-is-so-relevant-today

Atwood, Margaret. 1985. The Handmaid's Tale. Toronto: McClelland \& Bantam.

Atwood, Margaret. 2003. Oryx and Crake. New York: Nan A. Talese.

Atwood, Margaret. 2005. My Life in Science Fiction. Accessed June 30, 2020. http://revel. unice.fr/cycnos/index.html?id=616.

Atwood, Margaret. 2009. The Year of the Flood. New York: Knopf Doubleday.

Atwood, Margaret. 2011. "Margaret Atwood: the road to Ustopia". The Guardian October 14. Accessed June 30, 2020. https:/www.theguardian.com/books/2011/oct/14/margaret-atwood-road-to-ustopia.

Atwood, Margaret. 2013. MaddAddam. Toronto: McClelland \&Stewart.

Atwood, Margaret. 2015. The Heart Goes Last. Anchor.

Atwood, Margaret. 2018. "Canadian Monsters: Some Aspects of the Supernatural in Canadian Fiction." In Second Words: Selected Critical Prose 1960-1982. 229-254. Toronto: House of Anansi Press Inc.

Bloom, Harold. 2001. "Introduction.” In Margaret Atwood's The Handmaid's Tale, ed. Harold Bloom. 1-3. Philadelphia: Chelsea House Publishers.

Borbely, Carmen, and Petronia Popa Petrar. 2014. "“Natural-Born Cyborgs': Becoming Posthuman in Bio- and Cybertech Ustopias.” Ekphrasis 2: 142-158. Accessed June 30, 2020. https://ekphrasisjournal.ro/docs/R1/E12-11.pdf.

Borbely, Carmen-Veronica. 2015. Genealogies of Monstrosity: Constructions of Monstrous Corporeal Otherness in Contemporary British Fiction. Cluj-Napoca: Presa Universitară Clujeană.

Braidotti, Rosi. 1999. "Signs of Wonder and Traces of Doubt: On Teratology and Embodied Difference." In Feminist Theory and the Body: A Reader, ed. Janet Price and Margrit Shildrick, 290-302. New York: Routledge.

Collins Dictionary, sv. "teratogeny", accessed May 2, 2020, https://www.collinsdictionary.com/ dictionary/english/teratogeny.

Collins Dictionary. sv. "biopoiesis”, accessed May 3 2020, https://www.collinsdictionary.com/ dictionary/english/biopoiesis.

Csicsery-Ronay Jr, Istvan. 2009. "Empire.” In The Routledge Companion to Science Fiction, ed. Mard Bould, Andrew M. Butler, Adam Roberts, and Sherryl Vint, 362-373, Taylor \& Francis e-Library.

Dvorak, Marta. 2001. "What is Real/Reel? Margaret Atwood's 'Rearrangement of Shapes on a Flat Surface,' or Narrative as Collage.” In Margaret Atwood's The Handmaid's Tale, ed. Harold Bloom. 141-155. Philadelphia: Chelsea House Publishers.

Evans, Arthur B. 2009. "Nineteenth-Century SF." In The Routledge Companion to Science Fiction, ed. Mark Bould, Andrew M. Butler, Adam Roberts, and Sherryl Vint. 13-23. Oxon: Routledge. 
Friedman, Lester D. and Allison B. Kavey. 2016. Monstrous Progeny. A History of Frankenstein Narratives. New Jersey: Rutgers University Press.

Graham, Elaine L. 2002. Representations of the Post/Human: Monsters, Aliens and Others in Popular Culture. New Jersey: Rutgers University Press.

Harrison, John M. 2015. "The Heart Goes Last by Margaret Atwood." Review of The Heart Goes Last by Margaret Atwood. The Guardian, 23 September. https://www.theguardian. com/books/2015/sept/23/the-heart-goes-last-margaret-atwood-review-novel.

Hauskeller, Michael. 2016. Mythologies of Transhumanism. London: Palgrave Macmillan.

Herk, Aritha Van. 2003. "Welcome to Atwood's dystopia: plague, pigoons and pleeblands." The Globe and Mail, 26 April. Accessed June 30, 2020. https:/www.theglobeandmail.com/arts/ welcome-to-atwoods-dystopia-plague-pigoons-and-pleeblands/article750144/.

Hollinger, Veronica. 2009. "Posthumanism and cyborg theory." In The Routledge Companion to Science Fiction, ed. Mard Bould, Andrew M. Butler, Adam Roberts, and Sherryl Vint. 267-279. Taylor \& Francis e-Library.

Howells, Coral Ann. 1996. Margaret Atwood. New York: Macmillan Education.

Howells, Coral Ann. 2006. "Margaret Atwood's dystopian visions: The Handmaid's Tale and Oryx and Crake." In The Cambridge Companion to Margaret Atwood, ed. Coral Ann Howells. 161-176. New York: Cambridge University Press.

Hutcheon, Linda. 2000. A Theory of Parody. Illinois: University of Illinois Press.

Levine, George. 1973. "Frankenstein' and the Tradition of Realism.”. NOVEL: A Forum on Fiction7 (1): 14-30. Accessed June 23, 2020. https://www.jstor.org/stable/1345050.

Macpherson, Heidi Slettedahl. 2010. The Cambridge Introduction to Margaret Atwood. Cambridge: Cambridge University Press.

Malak, Amin. 2001. "Margaret Atwood's The Handmaid's Tale and the Dystopian Tradition." In Margaret Atwood's The Handmaid's Tale, ed. Harold Bloom, 3-11. Philadelphia: Chelsea House Publishers.

Nitchie, Elizabeth. 1970. Mary Shelley: Author of "Frankenstein." Westport, Connecticut: Greenwood Press.

Pordzik, Ralph. 2012. "The Posthuman Future of Man: Anthropocentrism and the Other of Technology in Anglo-American Science Fiction." Utopian Studies23 (2): 142-161. Accessed June 30 2020. https://www.jstor.org/stable/10.5325/utopianstudies.23.1.0142.

Rebecca, Baumann. 2018. Frankenstein 200: The Birth, Life, and Resurrection of Mary Shelley's Monster. Indiana: Indiana University Press.

Reiss, Michael. 2001. 'Biotechnology.' In The Concise Encyclopedia of the Ethics of New Technologies. Ed. Ruth Chadwick. 13-26. San Diego: Academic.

Savulescu, Julian. 2009. "Moral Status of Enhances Beings: What Do We Owe the Gods?" In Human Enhancement, ed. Savulescu Julian and Nick Bostrom. 211-247. New York: Oxford University Press.

Schmeink, Lars. 2016. Biopunk Dystopias. Genetic Engineering, Society and Science Fiction. Liverpool: Liverpool University Press.

Shelley, Mary Wollstonecraft. 2012. Frankenstein. Toronto: Broadview Press. 
Pobrane z czasopisma New Horizons in English Studies http://newhorizons.umcs.pl Data: 26/04/2023 09:17:39

Somacarrera, Pilar. 2006. "Power Politics: power and identity." In The Cambridge Companion to Margaret Atwood, ed. Coral Ann Howells. 43-58. New York: Cambridge University Press.

Stephen, Asma T. 2009. On Monsters: An Unnatural History of Our Worst Fears. New York: Oxford University Press.

Wolfe, Cary. 2010. What is Posthumanism? Minneapolis: University of Minnesota Press. 